\title{
Kurumsal Sosyal Sorumluluk Kampanyalarının Dijital Paydaşları; Sosyal Medya Fenomenleri
}

\author{
Filiz Balta Peltekoğlu (Prof. Dr.) \\ Marmara Üniversitesi İletişim Fakültesi \\ filiz@marmara.edu.tr \\ Emel Tozlu (Dr. Öğr. Üyesi) \\ İstanbul Gelişim Üniversitesi Uygulamalı Bilimler Yüksekokulu \\ etozlu@gelisim.edu.tr
}

Başvuru Tarihi: 04.05.2018

Yayına Kabul Tarihi: 25.06.2018

Yayınlanma Tarihi: 30.07.2018

Öz

2017 verilerine göre Nüfusun \%60 'ının internet kullandığı Türkiye'de, soysal medya kullananların oranı \%52. 18-29 yaş aralığında ise bu oran \%83'e yükselirken, en aktif sosyal medya platformları olarak da YouTube \% 57, Facebook \%54, Instagram $\%$ 49, Twitter \%44 ön plana çıkmaktadır. Söz konusu veriler, genç nüfusla iletişim kurabilmek için dijital ortamları öncelikli hale getirmektedir. En genel biçimde; kısa sürede çok sayıda insana erişme olanağı bulunan ve edindikleri bilgileri çevresindekilerle etkili biçimde paylaşan kişiler olarak tanımlanan kanaat önderleri, dijital iletişim sürecinin de önemli aktörleri olabilirler. Dijital ortamların kamuoyu önderi niteliğini kazanan sosyal medya fenomenlerinin paylaşım ve gönderilerinin etkisi iki aşamalı akış kuramı bağlamında ele alınabileceği gibi, iletilerin yayılma biçimi ise bir çeşit kulaktan kulağa iletişim mantığı ile açıklanabilir. Söz konusu yaklaşımla sosyal medya fenomenlerinin çok farklı konularda, ya da belirli bir konu üzerinde yoğunlaşan gönderilerinin, takipçilerinin tercihleri üzerinde etkili olacakları söylenebilir. Bu bağlamda, kamuoyu önderi niteliği taşıyan sosyal medya fenomenlerinin, sosyal sorumluluk kampanyalarının iletişiminde de etkili iletişim kaynağı olabilecekleri öngörülmektedir. Çalışmada sosyal medya kullanım oranının en yüksek olduğu yaş grubu üzerinde anket araştırması yapılmış ve takip edilen sosyal medya fenomeninin kamuoyu önderi işlevi üstlenerek, hedef kitlenin sosyal sorumluluk kampanyaları hakkında bilgi sahibi olması, kampanyalara katılması ve kampanyaların duyurulmasına katkıda bulunması konularındaki rolü ele alınmıștır.

Anahtar Kelimeler: Halkla İlişkiler, Sosyal Sorumluluk, Sosyal Medya Fenomenleri. 
Research Article

\title{
Social Media Influencers: The Digital Shareholders of Corporate Social Responsibility Campaigns
}

\author{
Filiz Balta Peltekoğlu (Prof. Dr.) \\ Marmara University Faculty of Communication \\ filiz@marmara.edu.tr \\ Emel Tozlu (Asst. Prof. Dr.) \\ İstanbul Gelişim University School of Applied Sciences \\ etozlu@gelisim.edu.tr
}

Date Received: 04.05.2018

Date Accepted: 25.06.2018

Date Published: 30.07.2018

\begin{abstract}
According to the data acquired in 2017, $60 \%$ of the population of Turkey uses internet and $52 \%$ of this population also use social media. As regards to social media, the age group of $18-29$ demonstrate a rate of $83 \%$ in terms of social media use, and the data indicate that YouTube, Facebook, Instagram and Twitter are the most prominent services with $57 \%, 54 \%, 49 \%$ and $44 \%$, respectively. These data render digital platforms significant since it shows that the young population applies to them in order to establish relationships. In the broadest terms, opinion leaders who are defined to be able to reach to a great number of people within a short time and to share the acquired information in the most efficient way can be the most important actors of the digital communication process. Acknowledged as the public leaders of digital platforms, the posts of social media influencers can be approached in terms of two-dimensional flow theory, and the propagation of these posts can be explained by a kind of Word od mouth comunication. As regards to such approach, it can be claimed that the posts of social media influencers that focus on one or more than one subjects can affect the preferences of their followers. In this sense, social media influencers who can also be defined as public leaders are believed to be an efficient source of communication for the promotion of social responsibility campaigns. This study carries out a survey on the aforementioned age group which has the highest rate of social media use and analyzes the role of public leader social media influencer in promoting social responsibility campaigns to the intended population, their participation in these campaigns and their contribution to the promotion of such campaigns.
\end{abstract}

Keywords: Public Relations, Social Responsibility, Social Media Influencers. 


\section{Giriş}

Günümüzde kurumsal sosyal sorumluluk kampanyaları, toplumsal hatta evrensel sorunlara çözüm stratejilerinin önemli bir halkasını oluşturmaktadır. Toplumların gelişmişlik düzeyleriyle doğrudan ilişkili olsa da, genel bir yaklaşımla kurumların çözüm bekleyen toplumsal sorunlara duyarsız kalarak toplumsal ve kurumsal sürdürülebilirliklerini sağlamaları imkansızdır. Küresel ve toplumsal sorunlar arasındaki geçişkenlik ise, kurumların toplumsal ve/veya evrensel sorunlara duyarsız kalarak var olmalarını daha da güçleștirmekte, sürdürülebilirliklerini sağlayabilmek için toplumsal sorunlara çözüm arayışında kurumlara aktif rol alma sorumluluğunu yüklemektedir. Türkiye'de, 2015 yılında kurumsal sosyal sorumlulukta iş dünyası tarafından en başarılı bulunan ve son dört yılda ilk üç sırayı paylaşan Koç Holding, Turkcell ve Eczacıbașı'nın gerçekleștirdikleri kurumsal sosyal sorumluluk kampanyalarının, Birleşmiş Milletlerin Bin Yıl Kalkınma hedefleri kapsamında yer alması ve UNGC'i imzalamış olmaları (Balta Peltekoğlu ve Tozlu, 2017, 5), evrensel ve toplumsal sorunların geçişkenliğinin farkına varmanın göstergelerinden bir tanesi olarak değerlendirilebilir.

Kurumların kurumsal sosyal sorumluluk kampanyaları için her aşamada iletişime gereksinimleri vardır. Zira kurumsal sosyal sorumluluk kampanyalarının farkındalığının arttırılarak, kampanyaya desteğin sağlanması, kampanyalardan kurumsal imaja ve itibara olumlu katkıda bulunacak geri dönüşün elde edilebilmesi ve kampanya kapsamında yapılan etkinliklerin gerçekleştirilebilmesi gibi adımların her biri iletişimle gerçekleştirilebilir. Özetle; kurumsal sosyal sorumluluk kampanyaları açısından iletişim kurumun sadece toplumsal duyarlılığının bir yansıması olarak imaj ve itibarla etkileşeceği için değil, toplumsal duyarlılığın arttırılmasına ilişkin katkısı nedeniyle de kampanyanın her aşamasında önem taşımaktadır (Balta Peltekoğlu ve Tozlu, 2017, 5).

\section{Kurumsal Sosyal Sorumluluk ve İletişim}

Günümüzde özellikle genç nüfus tarafından yaygın kullanım oranı, dijital mecrayı her türlü iletişim kampanyasında olduğu gibi, kurumsal sosyal sorumluluk kampanyalarının da etkili yöntemlerinden biri haline getirmektedir. 2017 verilerine göre, Türkiye'de 80 milyonluk nüfusun 48 milyonu internet kullanmaktadır. Bir başka deyişle Türkiye'de nüfusun \%60 ' internet kullanıcısıdır ve kullanıcıların \%87' isi internete her gün girmektedir. Türkiye'de sosyal medya kullanıcılarının oranı ise 48 milyon ile yine \%60 olarak ifade edilmektedir. Mobil telefon kullanıcı sayısı 71 milyondur, mobil cihazlardan soysal medya kullananların oranı ise 2016 yılında \%17 lik sayısal artışla \%52'ye yükselmiştir. Türkiye'de sosyal medya kullanıcılarına ilişkin rakamlara bakıldığında; en aktif sosyal medya platformlarının YouTube \% 57, Facebook \%54, Instagram \% 49, Twitter \%44, Whatsapp \%40 olduğu görülmektedir. Günümüz verilerine göre herhangi bir biçimde günde ortalama 3 saat sosyal medya kullanım süresi mobil üzerinden ise 2 saat 59 dakika olarak belirlenmektedir (http:// www.dijitalajanslar.com/internet-ve-sosyal-medya-kullanici-istatistikleri-2017/).

Rakamlara kullanıcı profili açısından bakıldığında 18-29 yaş aralığında bulunanların \%83'ünün sosyal medyayı kullandığı, 30-49 yaş aralığı için ise bu oranın \%77 olduğu görülmektedir (http://sosyalmedyakulubu.com.tr/sosyalmedya/sosyal-medyayien-cok-kimler-kullaniyor-infografik.html). Söz konusu veriler halkla ilişkiler kampanyalarında olduğu gibi, sosyal sorumluluk kampanyalarının iletişiminin de 
özellikle genç nüfus kapsamında dijital ortamlarda da sürdürülmesi zorunluluğunu ortaya koymaktadır. Bu bağlamda sosyal sorumluluk kampanyalarının duyurulması için geleneksel mecraların (radyo, televizyon, dergi, gazete vs.) yanında ve dışında özellikle genç nüfus açısından yüksek erişim olanağına sahip olan sosyal medyanın kullanılması günümüz istatistik verileri ışığında bir zorunluluk haline gelmiştir. Etkinlik ve duyuru sayfaları, kurumsal web sayfaları, diğer dijital iletişim yöntemlerinin yanında dijital ortamın kamuoyu önderleri olarak tanımlanabilecek sosyal medya fenomenlerinin paylaşımları da, kurumsal sosyal sorumluluk kampanyalarının etkili iletişimi açısından önem taşımaktadır. Zira, gerek bireyin kendi iradesiyle takip ettiği kamuoyu önderi rolü üstlenmeleri, gerekse kulaktan kulağa iletişim mantığı ile yayılan iletileri nedeniyle sosyal medya fenomenlerinin paylaşımlarının etkili olduğu söylenebilir.

\section{Kulaktan Kulağa İletişim ve Kamuoyu Önderi Olarak Sosyal Medya Fenomenleri}

Kamuoyu önderleri kendi ilişkileri ve networkleri içerisinde ürün, hizmet ve teknolojilerin yayılması sürecinde diğer insanların kararları üzerinde etkili olan kişiler olarak tanımlanmaktadır. Kulaktan kulağa iletişimin işleyişi, 1955'te Paul Lazarsfeld ve Elihu Katz'ın ortaya koydukları iki aşamalı akış kuramına atıfta bulunur (Sheth, Gardner ve Garrett, 1988, 114 ). İki aşamalı akış kuramına göre görüş ve düşünceler, kamuoyu önderlerinin medyadan aldıkları bilgileri analiz ederek ve yorumlayarak vardıkları sonuçları çevresindeki kişilerle paylaşmaları sonucunda benimsenmekte ve yayılmaktadır (Balta Peltekoğlu, 2016, 223). Valantine and Davis ise kamuoyu önderlerini, bir toplumda etkili ve merkezde olan kişiler olarak tanımlamışlardır. Valente ve Pumpuang ise kamuoyu önderlerinin kapsamını fikirler, davranışlar, inanışlar, motivasyon ve diğerlerinin davranışları üzerindeki etkiyi içerecek biçimde genişletmişlerdir. Rogers, kamuoyu önderliğini bir kişinin tutum ve davranışlarını kurduğu ilişki ile etkileyebilme derecesi ile açıklamıştır. Cho, Hwank ve Lee'ye göre (2012, 97-106) kamuoyu önderleri yeni bir ürün ya da düşüncenin yayılması ve benimsenmesi konularında formal ve/veya informal biçimde etkili olarak, farklı iletişim kanalları aracılığı ile diğer insanların seçimleri üzerinde belirleyici olmaktadır. Diğer yandan tüketicilerin karar verme sürecinde önemli etkileri olduğu bilinen kamuoyu önderlerinin, kulaktan kulağa iletişimin temsilcileri olarak, tüketicilerin karar verme sürecinde önemli etkiye sahip oldukları kabul edilmektedir. Aronson, Turner ve Carlsmith, güvenilirlik (credibility) ve tutum değişikliği arasındaki ilişkiyi ele aldıkları araştırmalarında iletişimde iletilerin etkililiği ile kaynağın güvenilirliği arasındaki bağı ortaya koymuşlardır. Bu yaklaşımla güvenilirlik, kaynağı inanılır yapan önemli bir özelliktir (Kağıtçıbaşı,1979, 170 aktaran Balta Peltekoğlu 2010 29). Mills ve Aronson tarafından yapılan araştırmada ise, kaynağın cazip karakter olması ile iletişimin etkililiği arasındaki ilişki ortaya konulmuştur. İletişim kaynağının sevilen ve cazip gelen bir kişi olması ise iletişim sürecinde önemli bir etken olarak belirmektedir (Kağıtçıbaşı, 1979,172 aktaran Balta Peltekoğlu 2010,29). Sevilen ve güvenilen kaynaktan gelen iletilerin alıcının tutum ve davranışları üzerinde etkili olacağını ortaya koyan etki alan araştırmaları, sosyal medya fenomenleri bağlamında değerlendirilebilir. Bu yaklaşımla takipçilerin kendi tercihleriyle izledikleri ve güvendikleri sosyal medya fenomenlerinin iletilerinden etkilenecekleri öngörüsünde bulunulabilir.

Dijital iletişimin ortaya çıkışıyla birlikte dünyada milyonlarca insan herhangi bir konuda kolaylıkla öneri ve düşüncelerini paylaşır hale gelmiştir. İnsanlar hemen her 
gün ilişkiler, filmler, yiyecekler, günlük olaylar v.b. hakkında düşünce ve önerilerini paylaşmaktadırlar (Rosen, 2000, 42-44). Sanal ağların oluşumuyla birlikte çok farklı demografik özelliklere sahip olan kamuoyu önderlerinin network'leri de, gönüllü takipçilerden oluşan dijital ağa taşınmıştır. Günümüz dijital iletişim ortamı açısından kesin bir geçerlilik taşımamakla birlikte Stokes ve Lomax'a (2002, 349-357) göre kulaktan kulağa iletişim bir haberci ve bir alıcı arasında marka, ürün veya hizmet hakkında ticari olmayan sözlü, yüz yüze iletişimdir. Bu yöntemle bireyler, fiziksel çevrelerinden, kitle iletişim araçlarından ve diğer bireylerden bilgi alırlar. East ve diğerlerine göre karşılıklı, hızlı ve herhangi bir tecimsel kaygı taşımayan kulaktan kulağa iletişim olası ürün seçimi ile ilgili bilgi edinme amacıyla, özellikle de hizmetin deneyimlenmemiş olması durumunda hizmet sektöründe oldukça etkili bir iletişim aracıdır (East vd., 2007, 175-184). Silverman'a göre $(2006,72)$ ise, günümüzde tutundurma faaliyetleri satış ve reklam çevresinde değil, kulaktan kulağa iletişim çevresinde dönmektedir. Bugüne kadar kavrama ilişkin pek çok tanım yapılmasına ve tek bir tanımı üzerinde fikir birliğine ulașılamamış olmasına rağmen, Bone'a göre $(1995,23)$ yapılan araştırmalar, müşterilerin satınalma davranışlarının gerçekleşmesi ve tekrarlanmasında kulaktan kulağa iletişimin önemini ortaya koymaktadır.

Sosyal medya fenomenleri ile ağ ortamında gerçekleşen iletişimde, fenomenlerin konumu kamuoyu önderliği ile açıklanabilirken, iletişimin işleyiş ve iletilerin yayılma süreci ise kulaktan kulağa iletişim ile açıklanabilir. Zira özellikle gençler arasında çok yaygın biçimde kullanılan sosyal medya, kişilerin görüş ve düşüncelerini kolaylıkla paylaşabildikleri, söz konusu paylaşımların kulaktan kulağa mantığı çok hızlı biçimde yayılma olanağı bulduğu ortam olmanın yanında, iletileri takip etmek üzere kişisel tercihle oluşmuş network'tür. Bu yaklaşımla gönüllü ve ağın merkezinde yer alan "güvenilen, sevilen" dijital kamuoyu önderinin söylemlerinin, takip eden kişilerin tercihleri üzerinde etkili olacağı söylenebilir. Bu nedenle dijital ortamda yürütülen kurumsal sosyal sorumluluk iletişiminde de sosyal medya fenomenlerinin kampanyaların etkili dijital paydaşları haline geldiği yorumuna ulaşılabilir. Özellikle East ve diğerlerinin yaklaşımı göz önüne alındığında "ticari bir kaygının olmadığı" ifadesi, kurumsal sosyal sorumluluk kampanyalarının iletişiminde aktif rol üstlenen sosyal medya fenomenleri açısından da önem kazanır. Nitekim Walster, Aronson, Abrahams tarafından yapılan araștırmaya göre iletişimde kaynağın bir beklentisinin söz konusu olmadığı durumlarda iletilerin etkisinin daha yüksek olduğu ortaya konulmuştur (Kağıtçıbaşı, 1979, 171 aktaran Balta Peltekoğlu 2010, 29).

\section{Araştırmanın Amacı}

İletişim teknolojilerinin yaygınlaşması ve iletişimde yaşanan değişim, halkla ilişkiler uygulamalarında olduğu gibi halkla ilişkiler açısından önemli işlevleri olan sosyal sorumluluk kampanyalarının iletişiminde de değişiklilere neden olmaktadır. Sosyal sorumluluk kampanyalarına katılımda, kişilerin tercihlerine yönelik güven, tavsiye, itibar vb. gibi bir çok değişken de kurumsal sosyal sorumluluk kampanyalarının iletişiminde de değișikliğe neden olmaktadır. İletişim etki alan araştırma sonuçları, güven, tavsiye, itibar vb. gibi bir çok değişkenin kişilerin tercihleri üzerinde etkili olduğunu ortaya koymaktadır. Bu yaklaşımla, özellikle genç nüfus açısından önemli iletişim mecraları haline gelen dijital ortamlar, kurumsal sosyal sorumluluk kampanyalarının iletişiminde önemli bir rol üstlenmekte, sosyal medya fenomenleri de kurumsal sosyal sorumluluk kampanyalarının önemli paydaşlarına dönüşmektedirler. Bu araştırmanın amacı kurumsal sosyal sorumluluk 
kampanyalarına katılım ve kampanyalara ilişkin bilgilerin paylaşımı sürecinde sosyal medyada kanaat önderi konumundaki fenomenlerin, dijital paydaşlar olarak kurumsal sosyal sorumluluk iletişimi sürecindeki rolü ve önemini incelemektir. Araştırma soruları aşağıdaki gibi oluşturulmuştur.

Araştırma Sorusu 1: Takip edilen sosyal medya fenomenin, kurumsal sosyal sorumluluk kampanyası konusunda paylaşımına güven değişkeni ile sevilen sanatçıların fenomen olarak takip edilmesi arasında pozitif ve anlamlı bir ilişki var midir?

Araştırma Sorusu 2: Takip edilen sosyal medya fenomenin, kurumsal sosyal sorumluluk kampanyası konusunda paylaşımına güven değişkeni ile sevilen sporcuların fenomen olarak takip edilmesi arasında pozitif ve anlamlı bir ilişki var midir?

Araştırma Sorusu 3: Takip edilen sosyal medya fenomenin, kurumsal sosyal sorumluluk kampanyası konusunda paylaşımına güven değişkeni ile sevilen bilim insanlarının fenomen olarak takip edilmesi arasında pozitif ve anlamlı bir ilişki var midir?

Araştırma Sorusu 4: Takip edilen sosyal medya fenomenin, kurumsal sosyal sorumluluk kampanyası konusunda paylaşımına güven değişkeni ile sevilen gazeteci ve televizyoncuların fenomen olarak takip edilmesi arasında pozitif ve anlamlı bir ilişki var mıdır?

Araştırma Sorusu 5: Takip edilen sosyal medya fenomenin, kurumsal sosyal sorumluluk kampanyası konusunda paylaşımına güven değişkeni ile ünlü olmayan kişilerin fenomen olarak takip edilmesi arasında pozitif ve anlamlı bir ilişki var mıdır?

\section{Araştırma Örneklemi ve Yöntemi}

Kurumsal sosyal sorumluluk kampanyalarına katılım sürecinde, sosyal medyanın kamuoyu önderi konumundaki fenomenlerin kurumsal sosyal sorumluluk iletişiminde etkisini incelemek amacıyla gerçekleştirilen anket uygulamasının örneklemini sosyal medyayı en yoğun oranda (\%83) kullanan yaş aralığında bulunmaları nedeniyle üniversite öğrencileri oluşturmuştur. Araştırma, kullanılan literatüre hakim oldukları gerekçesiyle İstanbul'da bulunan bir üniversitenin, halkla ilişkiler ve reklamcılık bölümü (lisans ve önlisans) öğrencileriyle gerçekleștirilmiştir. Sosyal medya kullanıcısı olan öğrencilerin en az bir sosyal medya fenomenini takip ediyor olmasının, araștırmanın kriteri olarak kabul edilmesi nedeniyle ise cevaplanan 160 formdan sosyal medya hesaplarını takip ettiğin fenomenler var mı?" Sorusuna "Evet" cevabı veren 115 form, analiz edilmek üzere dikkate alınmıștır. Anket formu aracılığı ile elde edilmiş olan bilgiler "SPSS for Windows 21.0" istatistik paket programına aktarılmıştır ve bu program aracılığıyla değerlendirilmiştir.

Sinırlılıklar: Sosyal medya fenomenlerinin kurumsal sosyal sorumluluk kampanyalarındaki önemini anlamaya yönelik olarak gerçekleştirilmiş bu araştırma, İstanbul'daki bir üniversite ile sınırlandırılmış olup, takipçilerin sosyal medya fenomenlerini hangi ölçütlere göre güvenilir buldukları konusu araştırmanın kapsamı dışında bırakılmıştır. 
Araştırma Verileri ve Sonuçları

Tablo 1: Araştırmaya Katılanların Demografik Özelikleri

\begin{tabular}{|llll|}
\hline Demografik Değişkenler & Demografik Özellikler & N & $\%$ \\
\hline Cinsiyet & Kadın & 77 & 67,0 \\
& Erkek & 38 & 33,0 \\
\hline Eğitim Durumu & Üniversite Öğrencisi & 115 & 100 \\
\hline Medeni Durumu & Bekar & 115 & 100 \\
\hline Yaş grubu & $18-27$ & 113 & 98,3 \\
& $28-37$ & 2 & 1,7 \\
\hline Aylık net gelir (kişisel) & 1.000 TL'den az & 17 & 14,8 \\
& $1.001-2.000$ TL arası & 28 & 24,3 \\
& $2.001-4.000$ TL arası & 40 & 34,8 \\
& $4.001-5.000$ TL arası & 13 & 11,3 \\
& 5.000 TL ve üzeri & 17 & 14,8 \\
\hline
\end{tabular}

Araştırmaya katılanların demografik özelliklerine bakıldığında cinsiyet değişkeni bağlamında kadın katılımcı sayısının, erkek katılımcıların sayısıyla aynı olduğu, eğitim durumu değişkeni bağlamında tamamının üniversite öğrencisi olması nedeniyle fark olmadığı, yaş değişkenine bakıldığında 18-27 yaş arası grubun açık ara bir farkla \%98,3'lük dilime yerleștiği. Aylık net gelir değişkenine bakıldığında ise 2.001-4000 TL rakamı \%34,8’lik dilim olarak en yüksek oranla karşımıza çıkmaktadır.

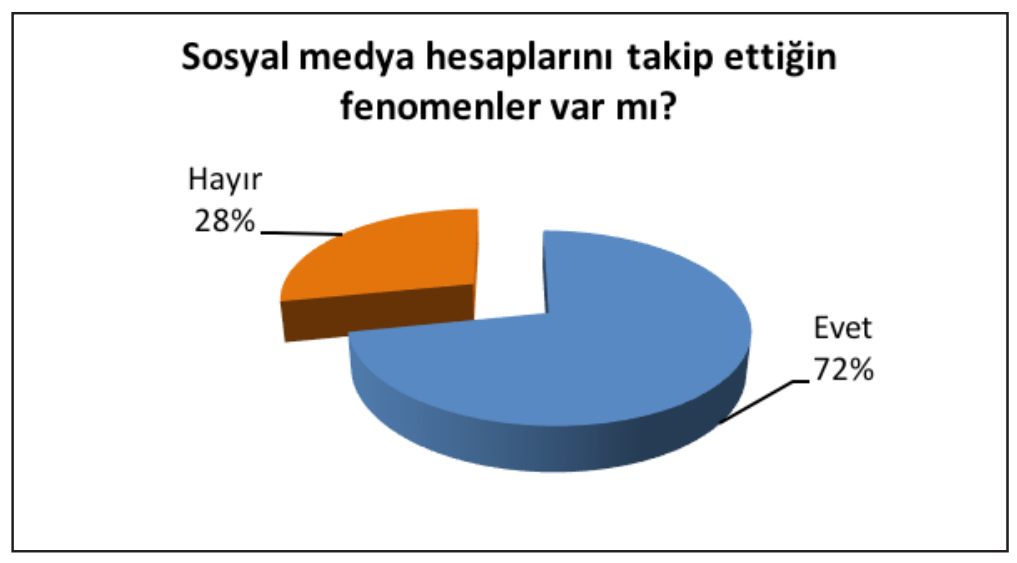

Şekil 1: Sosyal Medya Fenomenlerini takip

Katılımcıların en az bir sosyal medya fenomenini takip durumu kıstas alınması nedeniyle "medya hesaplarını takip ettiğin fenomenler var mı?" sorusu sorulmuștur. Katılımcıların büyük bir çoğunluğu \%72'lik dilim ile evet cevabı vermiştir bu durum sosyal medya kullanıcılarının sosyal medya fenomenlerine olan ilgisini gösterir niteliktedir. Takipçilerin gönüllü olarak izledikleri sosyal medya fenomenlerinin etki potansiyeline de dikkat çekmektedir. 
Tablo 2: Sosyal Medya Fenomenleri ve Kaynak Etkisi

\begin{tabular}{|c|c|c|c|c|c|c|}
\hline & & 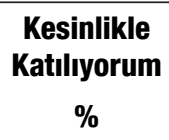 & $\begin{array}{c}\text { Katilıyorum } \\
\%\end{array}$ & $\begin{array}{c}\text { Kararsızım } \\
\%\end{array}$ & $\begin{array}{c}\text { Katılmıyorum } \\
\%\end{array}$ & $\begin{array}{c}\text { Hiç } \\
\text { Katılmıyorum } \\
\%\end{array}$ \\
\hline \multirow{7}{*}{ 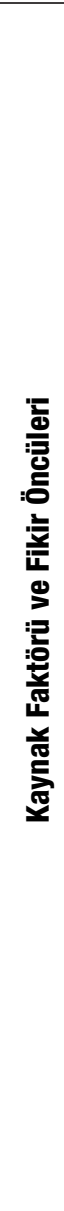 } & $\begin{array}{l}\text { Takip ettiğim sosyal } \\
\text { medya fenomenlerinin } \\
\text { her gün mutlaka sosyal } \\
\text { medya paylaşımlarına } \\
\text { bakarım. }\end{array}$ & 15,7 & 32,2 & 18,3 & 25,2 & 8,7 \\
\hline & $\begin{array}{l}\text { Takip ettiğim sosyal } \\
\text { medya fenomeninin } \\
\text { farklı konulara yaklaşımı } \\
\text { beni ilgilendirir. }\end{array}$ & 29,6 & 51,3 & 8,7 & 5,2 & 5,2 \\
\hline & $\begin{array}{l}\text { Takip ettiğim sosyal } \\
\text { medya fenomenlerinin } \\
\text { arasında sevdiğim } \\
\text { sanatçılar yer almaktadır. }\end{array}$ & 27,0 & 42,6 & 9,6 & 15,7 & 5,2 \\
\hline & $\begin{array}{l}\text { Takip ettiğim sosyal } \\
\text { medya fenomenlerinin } \\
\text { arasında sevdiğim } \\
\text { sporcular yer almaktadır. }\end{array}$ & 29,6 & 32,2 & 15,7 & 14,8 & 7,8 \\
\hline & $\begin{array}{l}\text { Takip ettiğim sosyal } \\
\text { medya fenomenlerinin } \\
\text { arasında bilim insanları } \\
\text { yer almaktadır. }\end{array}$ & 18,3 & 27,0 & 25,2 & 20,9 & 8,7 \\
\hline & $\begin{array}{l}\text { Takip ettiğim sosyal } \\
\text { medya fenomenlerinin } \\
\text { arasında gazeteciler } \\
\text { ve televizyoncular } \\
\text { yer almaktadır. }\end{array}$ & 21,7 & 38,3 & 21,7 & 13,9 & 4,3 \\
\hline & $\begin{array}{l}\text { Takip ettiğim sosyal } \\
\text { medya fenomenlerinin } \\
\text { arasında hiç ünlü olmayan } \\
\text { kişiler yer almaktadır. }\end{array}$ & 22,6 & 34,8 & 22,6 & 13,9 & 6,1 \\
\hline
\end{tabular}

Sosyal Medya Fenomenleri ve Kaynak özelliklerini belirlemek amacıyla, beşli likert ölçeği kullanılarak oluşturulan frekans analiz tablosuna bakıldığında tüm soruların cevaplarında "Kesinlikle Katılıyorum" hanesine yönelik pozitif bir ivme görülmektedir. Buradan yola çıkarak üniversite öğrencilerinin sosyal medya fenomenlerini kaynak konumunda koydukları bu bağlamda fikir öncüsü olarak nitelendirebilecekleri ön görülebilmektedir. Soruların cevaplarına bakıldığında sanatçıların, sporcuların, bilim insanlarının, gazetecilerin ve televizyoncuların fikir öncüsü olarak konumlandırıldıklarını ancak teknolojinin "fikir öncüsü" kamuoyu önderi kavramını "sosyal medya fenomeni" kavramına dönüștürdügüne işaret etmektedir. 
Tablo 3: Sosyal Sorumlulukta Sosyal Medya Fenomenleri Etkisi

\begin{tabular}{|c|c|c|c|c|c|c|}
\hline & $\begin{array}{c}\text { Kesinlikle } \\
\text { Katılıyorum } \\
\%\end{array}$ & $\begin{array}{c}\text { Katılıyorum } \\
\%\end{array}$ & $\begin{array}{c}\text { Kararsızım } \\
\%\end{array}$ & $\begin{array}{c}\text { KatıImıyorum } \\
\%\end{array}$ & 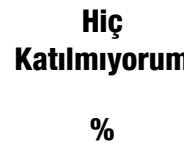 \\
\hline \multirow{7}{*}{ 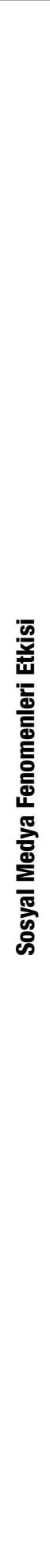 } & $\begin{array}{l}\text { Takip ettiğim sosyal } \\
\text { medya fenomeni } \\
\text { bir KSS (kurumsal } \\
\text { sosyal sorumluluk) } \\
\text { kampanyasına destek } \\
\text { verirse mutlaka bende } \\
\text { kampanyaya destek ile } \\
\text { katılımda bulunurum. }\end{array}$ & 20 & 27 & 34,8 & 13,91 & 4,35 \\
\hline & $\begin{array}{l}\text { KSS (kurumsal } \\
\text { sosyal sorumluluk) } \\
\text { kampanyalarını } \\
\text { takip ettiğim sosyal } \\
\text { medya fenomenimin } \\
\text { paylaşımlarından } \\
\text { öğreniyorum } \\
\end{array}$ & 15,6 & 25,2 & 20,9 & 29,6 & 8,7 \\
\hline & $\begin{array}{l}\text { Takip ettiğim sosyal } \\
\text { medya fenomeni } \\
\text { bir KSS(kurumsal } \\
\text { sosyal sorumluluk) } \\
\text { kampanyası paylaşırsa } \\
\text { mutlaka bende kendi } \\
\text { sayfamda paylaşıım }\end{array}$ & 14,8 & 17,4 & 31,3 & 26,9 & 10,4 \\
\hline & $\begin{array}{l}\text { Takip ettiğim sosyal } \\
\text { medya fenomeni bir } \\
\text { KSS (kurumsal sosyal } \\
\text { sorumluluk) kampanyası } \\
\text { başlatırsa mutlaka } \\
\text { çevremdekilerinde } \\
\text { haberdar ederim. }\end{array}$ & 19,1 & 35,6 & 24,3 & 15,6 & 5,2 \\
\hline & $\begin{array}{l}\text { Takip ettiğim sosyal } \\
\text { medya fenomeni } \\
\text { bir KSS(kurumsal } \\
\text { sosyal sorumluluk) } \\
\text { kampanyası başlatırsa bu } \\
\text { kampanyanın güvenilir } \\
\text { olduğunu düşünürüm. }\end{array}$ & 13,4 & 37,3 & 30,4 & 13,9 & 5,2 \\
\hline & $\begin{array}{l}\text { Takip ettiğim sosyal } \\
\text { medya fenomeni bir } \\
\text { kurum ile ilgili KSS } \\
\text { (kurumsal sosyal } \\
\text { sorumluluk) kampanyası } \\
\text { başlatırsa, kuruma } \\
\text { yönelik düşüncelerimi } \\
\text { olumlu yönde etkiler. } \\
\end{array}$ & 12 & 33,9 & 32,2 & 16,5 & 5,2 \\
\hline & \begin{tabular}{|l} 
Takip ettiğim sosyal \\
medya fenomenin, \\
kurumsal sosyal \\
sorumluluk kampanyası \\
konusunda paylaşım \\
yapması takibimi \\
olumlu olarak etkiler.
\end{tabular} & 30,4 & 41,7 & 18,2 & 6,9 & 3,5 \\
\hline
\end{tabular}

Sosyal Sorumluluk kampanyalarının iletişiminde ileti kaynağı olarak Sosyal Medya Fenomenlerinin rolünü belirlemek amacıyla, beşli likert ölçeği kullanılarak oluşturulan frekans analiz tablosuna bakıldığında tüm soruların cevaplarında takip edilen sosyal medya fenomeni bir kurumsal sosyal sorumluluk kampanyası 
başlatırsa, kampanyaya destek verirse ve/veya bir kampanyayı paylaşırsa takipçinin tepkisinin ne olacağı ile ilgili sorulara verilen yanıtlarda "Kesinlikle Katıllyorum" hanesine yönelik pozitif bir ivme görülmektedir. Buradan yola çıarak üniversite öğrencilerinin sosyal medya fenomenleri doğrultusunda kulaktan kulağa iletişime geçerek, sosyal sorumluluk kampanyalarına katılımlarının ve kampanyaya ilişkin paylaşımlarının yüksek ölçüde olabileceği görülmektedir. Bu sonuç ile ilgili olarak sosyal medyada iletişimin kulaktan kulağa iletişimin işleyiş biçimiyle benzeştiği ve kurumsal sosyal sorumluluk kampanyalarının iletişiminde sosyal medya fenomenlerinin iki aşamalı akış kuramındaki kamuoyu önderler rolünü üstlendiği yorumu yapılabilmektedir.

Tablo 4: Takip Edilen Sosyal Medya Fenomenin, Kurumsal Sosyal Sorumluluk Kampanyası Konusunda Paylaşımına Güven Değişkeni ile Sevilen Sanatçıların Fenomen Olarak Takip Edilmesi Arasındaki İliskiyi Belirlemek Üzere Yapılan Pearson Çarpım Moment Korelasyon Analizi Sonuçları

\begin{tabular}{|c|c|c|c|}
\hline & & $\begin{array}{c}\text { Takip Edilen } \\
\text { Sosyal Medya } \\
\text { Fenomenin, } \\
\text { Kurumsal Sosyal } \\
\text { Sorumluluk } \\
\text { Kampanyası } \\
\text { Konusunda } \\
\text { Paylaşımına } \\
\text { Güven }\end{array}$ & $\begin{array}{c}\text { Sevilen } \\
\text { Sanatçıların } \\
\text { Fenomen Olarak } \\
\text { Takip Edilmesi }\end{array}$ \\
\hline \multirow{3}{*}{$\begin{array}{l}\text { Takip Edilen Sosyal Medya } \\
\text { Fenomenin, Kurumsal Sosyal } \\
\text { Sorumluluk Kampanyası } \\
\text { Konusunda Paylaşımına Güven }\end{array}$} & Pearson Correlation & 1 &, $671^{\star \star}$ \\
\hline & Sig. (2-tailed) & &, 000 \\
\hline & $N$ & 115 & 115 \\
\hline \multirow{3}{*}{$\begin{array}{l}\text { Sevilen Sanatçıların Fenomen } \\
\text { Olarak Takip Edilmesi }\end{array}$} & Pearson Correlation &, $671^{\star \star}$ & 1 \\
\hline & Sig. (2-tailed) &, 000 & \\
\hline & $N$ & 115 & 115 \\
\hline
\end{tabular}

Takip edilen sosyal medya fenomenin, kurumsal sosyal sorumluluk kampanyası konusunda paylaşımına güven değişkeni ile sevilen sanatçıların fenomen olarak takip edilmesi arasındaki ilişkiyi belirlemek üzere yapılan pearson çarpım moment korelasyon analizi sonuçları arasında pozitif ve anlamlı bir ilişki olduğu bulunmuştur $(r=0,671 ; \quad p<0,05)$. Buradan yola çıkılarak takip edilen fenomen konumundaki sanatçıya güven arttıkça, sosyal sorumluluk uygulamalarına yönelik paylaşımların artacağı sonucu elde edilebilmektedir. Söz konusu veriler, sosyal medya fenomenlerine duyulan güven ile etkili bir iletişim kaynağı olmaları arasındaki ilişkiye vurgu yapmaktadır. Bu yaklaşımla, sosyal medya fenomenlerine takipçileri tarafından kamuoyu önderi rolü yüklendiği söylenebilir. 
Tablo 5: Takip Edilen Sosyal Medya Fenomenin, Kurumsal Sosyal Sorumluluk Kampanyası Konusunda Paylaşımına Güven Değiş̧keni ile Sevilen Sporcuların Fenomen Olarak Takip Edilmesi Arasındaki İlişkiyi Belirlemek Üzere Yapılan Pearson Çarpım Moment Korelasyon Analizi Sonuçları

\begin{tabular}{|c|c|c|c|}
\hline & & $\begin{array}{c}\text { Takip Edilen Sosyal } \\
\text { Medya Fenomenin, } \\
\text { Kurumsal Sosyal } \\
\text { Sorumluluk } \\
\text { Kampanyası } \\
\text { Konusunda } \\
\text { Paylaşımına Güven }\end{array}$ & $\begin{array}{c}\text { Sevilen } \\
\text { Sporcuların } \\
\text { Fenomen } \\
\text { Olarak Takip } \\
\text { Edilmesi }\end{array}$ \\
\hline \multirow{3}{*}{$\begin{array}{l}\text { Takip Edilen Sosyal Medya Fenomenin, } \\
\text { Kurumsal Sosyal Sorumluluk Kampanyası } \\
\text { Konusunda Paylaşımına Güven }\end{array}$} & Pearson Correlation & 1 &, $572^{\star \star}$ \\
\hline & Sig. (2-tailed) & & ,000 \\
\hline & $N$ & 115 & 115 \\
\hline \multirow{3}{*}{$\begin{array}{l}\text { Sevilen Sporcuların Fenomen } \\
\text { Olarak Takip Edilmesi }\end{array}$} & Pearson Correlation &, $572^{\star \star}$ & 1 \\
\hline & Sig. (2-tailed) & ,000 & \\
\hline & $N$ & 115 & 115 \\
\hline
\end{tabular}

Takip edilen sosyal medya fenomenin, kurumsal sosyal sorumluluk kampanyası konusunda paylaşımına güven değişkeni ile sevilen sporcuların fenomen olarak takip edilmesi arasındaki ilişkiyi belirlemek üzere yapılan pearson çarpım moment korelasyon analizi sonuçları arasında pozitif ve anlamlı bir ilişki olduğu bulunmuştur $(r=0,572 ; \quad p<0,05)$. Buradan yola çıkılarak takip edilen fenomen konumundaki sporcuya güven arttıkça, sosyal sorumluluk uygulamalarına yönelik paylaşımların artacağı ve sosyal medya fenomeninin kamuoyu önderi rolü oynayacağı sonucuna ulaşılabilmektedir.

Tablo 6: Takip Edilen Sosyal Medya Fenomenin, Kurumsal Sosyal Sorumluluk Kampanyası Konusunda Paylaşımına Güven Değişkeni ile Sevilen Bilim İnsanlarının Fenomen Olarak Takip Edilmesi Arasındaki Ilişskiyi Belirlemek Üzere Yapılan Pearson Çarpım Moment Korelasyon Analizi Sonuçları

\begin{tabular}{|c|c|c|c|}
\hline & & $\begin{array}{c}\text { Takip Edilen Sosyal } \\
\text { Medya Fenomenin, } \\
\text { Kurumsal Sosyal } \\
\text { Sorumluluk Kampanyası } \\
\text { Konusunda } \\
\text { Paylaşımına Güven }\end{array}$ & $\begin{array}{l}\text { Bilim İnsanlarının } \\
\text { Fenomen Olarak } \\
\text { Takip Edilmesi }\end{array}$ \\
\hline \multirow{3}{*}{$\begin{array}{l}\text { Takip Edilen Sosyal Medya } \\
\text { Fenomenin, Kurumsal Sosyal } \\
\text { Sorumluluk Kampanyası } \\
\text { Konusunda Paylaşımına Güven }\end{array}$} & Pearson Correlation & 1 &, $681^{* \star}$ \\
\hline & Sig. (2-tailed) & & ,000 \\
\hline & $N$ & 115 & 115 \\
\hline \multirow{3}{*}{$\begin{array}{l}\text { Sevilen Bilim İnsanlarının } \\
\text { Fenomen Olarak Takip Edilmesi }\end{array}$} & Pearson Correlation &, $681^{* *}$ & 1 \\
\hline & Sig. (2-tailed) & ,000 & \\
\hline & $N$ & 115 & 115 \\
\hline
\end{tabular}

Takip edilen sosyal medya fenomenin, kurumsal sosyal sorumluluk kampanyası konusunda paylaşımına güven değişkeni ile sevilen bilim insanlarının fenomen olarak takip edilmesi arasındaki ilişkiyi belirlemek üzere yapılan pearson çarpım moment korelasyon analizi sonuçları arasında pozitif ve anlamlı bir ilişki olduğu bulunmuştur $(\mathrm{r}=0,681 ; \mathrm{p}<0,05)$. Buradan yola çıkılarak takip edilen fenomen konumundaki bilim insanına güven arttıkça, sosyal sorumluluk uygulamalarına yönelik paylaşımların artacağı sonucu elde edilebilmektedir. 
Tablo 7: Takip Edilen Sosyal Medya Fenomenin, Kurumsal Sosyal Sorumluluk Kampanyası Konusunda Paylaşımına Güven Değiş̧keni ile Sevilen Gazeteci ve Televizyoncuların Fenomen Olarak Takip Edilmesi Arasındaki İlişkiyi Belirlemek Üzere Yapılan Pearson Çarpım Moment Korelasyon Analizi Sonuçları

\begin{tabular}{|c|c|c|c|}
\hline & & \begin{tabular}{|c|} 
Takip Edilen Sosyal Medya \\
Fenomenin, Kurumsal Sosyal \\
Sorumluluk Kampanyası \\
Konusunda Paylaşımına Güven
\end{tabular} & $\begin{array}{c}\text { Gazeteci ve } \\
\text { Televizyoncuların } \\
\text { Fenomen Olarak } \\
\text { Takip Edilmesi }\end{array}$ \\
\hline \multirow{3}{*}{$\begin{array}{l}\text { Takip Edilen Sosyal } \\
\text { Medya Fenomenin, } \\
\text { Kurumsal Sosyal } \\
\text { Sorumluluk Kampanyası } \\
\text { Konusunda } \\
\text { Paylaşımına Güven }\end{array}$} & Pearson Correlation & 1 &, $361^{\star \star}$ \\
\hline & Sig. (2-tailed) & &, 000 \\
\hline & $\mathrm{N}$ & 115 & 115 \\
\hline \multirow{3}{*}{$\begin{array}{l}\text { Gazeteci ve } \\
\text { Televizyoncuların } \\
\text { Fenomen Olarak } \\
\text { Takip Edilmesi }\end{array}$} & Pearson Correlation &, $361^{\star \star}$ & 1 \\
\hline & Sig. (2-tailed) & ,000 & \\
\hline & $\mathrm{N}$ & 115 & 115 \\
\hline
\end{tabular}

Takip edilen sosyal medya fenomenin, kurumsal sosyal sorumluluk kampanyası konusunda paylașımına güven değişkeni ile sevilen gazeteci ve televizyoncuların fenomen olarak takip edilmesi arasındaki ilişkiyi belirlemek üzere yapılan pearson çarpım moment korelasyon analizi sonuçları arasında pozitif ve anlamlı bir ilişki olduğu bulunmuştur $(r=0,361 ; p<0,05)$. Buradan yola çıkılarak takip edilen fenomen konumundaki gazeteci ve televizyonculara güven arttıkça, sosyal sorumluluk uygulamalarına yönelik paylaşımların artacağı sonucu elde edilebilmektedir.

Tablo 8: Takip Edilen Sosyal Medya Fenomenin, Kurumsal Sosyal Sorumluluk Kampanyası Konusunda Paylaşımına Güven Değişkeni ile Ünlü Olmayan Kişilerin Fenomen Olarak Takip Edilmesi Arasındaki İlişkiyi Belirlemek Üzere Yapılan Pearson Çarpım Moment Korelasyon Analizi Sonuçları

\begin{tabular}{|c|c|c|c|}
\hline & & $\begin{array}{c}\text { Takip Edilen } \\
\text { Sosyal Medya } \\
\text { Fenomenin, } \\
\text { Kurumsal Sosyal } \\
\text { Sorumluluk } \\
\text { Kampanyası } \\
\text { Konusunda } \\
\text { Paylaşımına } \\
\text { Güven }\end{array}$ & $\begin{array}{l}\text { Ünlü Olmayan } \\
\text { Kişilerin Fenomen } \\
\text { Olarak Takip } \\
\text { Edilmesi }\end{array}$ \\
\hline \multirow{3}{*}{$\begin{array}{l}\text { Takip Edilen Sosyal Medya Fenomenin, } \\
\text { Kurumsal Sosyal Sorumluluk Kampanyası } \\
\text { Konusunda Paylaşımına Güven }\end{array}$} & $\begin{array}{l}\text { Pearson } \\
\text { Correlation }\end{array}$ & 1 &, $873^{\star \star}$ \\
\hline & Sig. (2-tailed) & & ,000 \\
\hline & $\mathrm{N}$ & 115 & 115 \\
\hline \multirow{3}{*}{$\begin{array}{l}\text { Ünlü Olmayan Kişilerin Fenomen } \\
\text { Olarak Takip Edilmesi }\end{array}$} & $\begin{array}{l}\text { Pearson } \\
\text { Correlation }\end{array}$ &, $873^{\star *}$ & 1 \\
\hline & Sig. (2-tailed) & ,000 & \\
\hline & $\mathrm{N}$ & 115 & 115 \\
\hline
\end{tabular}

Takip edilen sosyal medya fenomenin, kurumsal sosyal sorumluluk kampanyası konusunda paylaşımına güven değişkeni ile ünlü olmayan kişilerin fenomen olarak takip edilmesi arasındaki ilişkiyi belirlemek üzere yapılan pearson çarpım moment korelasyon analizi sonuçları arasında pozitif ve anlamlı bir ilişki olduğu bulunmuştur $(\mathrm{r}=0,873 ; \mathrm{p}<0,05)$. Buradan yola çıkılarak takip edilen 
fenomen konumundaki ünlü olamayan kişilere güven arttıkça, sosyal sorumluluk uygulamalarına yönelik paylaşımların artacağı, dolayısıyla takipçilerin kendi tercihleri ile belirleyerek takip ettikleri sosyal medya fenomenlerinin kamuoyu önderi işlevini üstlenmelerinin ve paylaşımlarının etkili olmasının ünlü olmaları ya da olmamalarından çok güven duyulmaları ve sevilmeleriyle ilişkili olduğunu ortaya koyduğu sonucuna ulaşılabilmektedir.

\section{Sonuç ve Öneriler}

Kurumsal sosyal sorumluluk kampanyaları farkındalığının arttırılması, kampanyaya desteğin sağlanması ve kampanya kapsamında yapılan etkinliklerin gerçekleştirilebilmesi vb. gibi nedenlerle iletişime gereksinim duymaktadır. Hemen her türlü iletişim ve Halkla İlişkiler kampanyasında olduğu gibi kurumsal sosyal sorumluluk kampanyalarının iletişimi açısından da, kamuoyu önderleri önemli paydaşlardır. Ancak giderek özellikle genç nüfus arasında en yaygın iletişim ortamı haline gelen dijital iletişim, kamuoyu önderlerini de söz konusu ortama taşımış, sosyal medya fenomenleri yeni iletişim ortamlarının dijital paydaşları haline gelmişlerdir. Paul Lazarsfeld ve Elihu Katz'ın iki aşamalı akış kuramında ortaya koydukları kamuoyu önderi etkisi, sosyal medya fenomenlerinin gündemi takipçilerine ulaştıran rolleri açısından da açıklayıcıdır. Sosyal medya fenomenlerinin takipçileriyle iletişimleri ise (WOM) kulaktan kulağa iletişim modeline benzemekte, iletiler hızlı biçimde geniş kitlelere yayılabilmektedir.

Kurumsal sosyal sorumlulukta ileti kaynağı olarak Sosyal Medya Fenomenlerinin rolü ve önemini belirlemek amacıyla gerçekleştirilmiş olan ancak takipçilerin sosyal medya fenomenlerini neye göre ve neden güvenilir buldukları sorularının kapsam dışında bırakıldığı araştırma sonuçları doğrultusunda "Takip edilen sosyal medya fenomeninin, kurumsal sosyal sorumluluk kampanyası konusunda paylaşımına güven değişkeni" ile korelasyon testine tabi tutulmuş olan değişkenler en yüksekten en düşüğe doğru sıralandığında; ünlü olmayan kişiler ( $r=0,873)$, bilim insanları $(r=0,681)$, sanatçlar $(r=0,671)$, sporcular $(r=0,572)$, gazeteci ve televizyoncular $(r=0,361)$ 'dir. Tüm araştırma sonuçlarının anlamlı ve pozitif değerlerden oluşması nedeniyle güven kavramının sosyal medya fenomeninin konumu ne olursa olsun etken faktör olduğu ortaya çıkmaktadır. Bu bağlamda beşinci araştırma sorusu olan "Takip edilen sosyal medya fenomenin, kurumsal sosyal sorumluluk kampanyası konusunda paylaşımına güven değişkeni ile ünlü olmayan kişilerin fenomen olarak takip edilmesi arasında pozitif ve anlamlı bir ilişki var mıdır?" en yüksek etki ile pozitif ve anlamlı şekilde karşılık bulmuştur. Buradan yola çıkarak ünlü olmayan kişiler de güvenilir oldukları oranda paylaşmış oldukları sosyal sorumluluk kampanyalarına katılımın, gösterilen duyarlılığın o kadar yüksek olabileceği ön görülebilmektedir. Üçüncü araștırma sorusu olan “Takip edilen sosyal medya fenomenin, kurumsal sosyal sorumluluk kampanyası konusunda paylaşımına güven değişkeni ile sevilen bilim insanlarının fenomen olarak takip edilmesi arasında pozitif ve anlamlı bir ilişki var mıdır?" en yüksek ikinci etki ile pozitif ve anlamlı şekilde elde edilmiştir. Buradan yola çıkarak bilim insanlarına ne kadar güvenilirse paylaşmış oldukları sosyal sorumluluk kampanyalarına iştirakin o kadar yüksek olabileceği ön görülebilmektedir. Bu noktada sosyal medyada paylaşım yapan unvan sahibi bilim insanının da diğer takip edilen sosyal medya fenomenleriyle benzer biçimde yapmış olduğu paylaşımların ikna edici gücü güven faktörü ile doğrudan ilişkili olduğu görülmektedir. 
Birinci araştırma sorusu olan "Takip edilen sosyal medya fenomenin, kurumsal sosyal sorumluluk kampanyası konusunda paylaşımına güven değişkeni ile sevilen sanatçların fenomen olarak takip edilmesi arasında pozitif ve anlamlı bir ilişki var mıdır?" Buradan yola çıkarak sanatçllara ne kadar güvenilirse paylaşmış oldukları sosyal sorumluluk kampanyalarına iştirakin o kadar yüksek olabileceği ön görülebilmektedir. $\mathrm{Bu}$ bağlamda sosyal medyada sanatçllar tarafından yapılan paylaşımların tümünün kurumsal sosyal sorumluluk faaliyetine katılım sağlayamayacağı öngörüsünde bulunulabilir.

İkinci araştırma sorusu olan "Takip edilen sosyal medya fenomenin, kurumsal sosyal sorumluluk kampanyası konusunda paylaşımına güven değişkeni ile sevilen sporcuların fenomen olarak takip edilmesi arasında pozitif ve anlamlı bir ilişki var mıdır?" en yüksek dördüncü etki ile pozitif ve anlamlı șekilde elde edilmiştir. Buradan yola çıkarak sporculara ne kadar güvenilirse paylaşmış oldukları sosyal sorumluluk kampanyalarına iştirakin o kadar yüksek olabileceği varsayılabilmektedir.

Dördüncü araștırma sorusu olan "Takip edilen sosyal medya fenomenin, kurumsal sosyal sorumluluk kampanyası konusunda paylaşımına güven değişkeni ile sevilen gazeteci ve televizyoncuların fenomen olarak takip edilmesi arasında pozitif ve anlamlı bir ilişki var mıdır?" en yüksek beşinci etki ile pozitif ve anlamlı şekilde elde edilmiştir. Buradan yola çıkarak gazeteci ve televizyonculara ne kadar güvenilirse paylaşmış oldukları sosyal sorumluluk kampanyalarına iștirakin o kadar yüksek olabileceği varsayılabilmektedir. Bu bağlamda gazeteci ve televizyoncuların güvenilir olarak bulundukları takdirde yapmış oldukları sosyal sorumluluk kampanyalarına karşı olan güvenin arttığı yorumu yapılabilmektedir tabi bu noktada bağlı oldukları kurumlara karşı güven noktası göz ardı edilmemesi gereklidir.

Araştırmanın analiz sonuçlarından yola çıkarak kamuoyu önderi niteliği taşıyan sosyal medya fenomenlerinin, sosyal sorumluluk kampanyalarının iletişiminde de etkili iletişim kaynağı oldukları sonucuna ulaşılmaktadır. Ancak takip edilen sosyal medya fenomenlerinin takipçileri üzerindeki etkisi Aronson, Turner ve Carlsmith $(1963,31)$, güvenilirlik ve tutum değişikliği arasındaki ilişkiyi ele aldıkları ve iletişimde iletilerin etkililiğinin kaynağın güvenilirliği arasındaki bağı ortaya koydukları araştırma sonuçları bağlamında bakıldığında, sosyal medya fenomeninin güvenilir olması ile takipçilerinin tutum ve davranışları üzerindeki etkisinin arttığı görülmüştür. Söz konusu veriler ışığında, sosyal medya fenomenlerinin sanal ortamın kamuoyu önderi işlevini üstlenecekleri, kamuoyu önderine duyulan güven oranında ise etkililiğin artacağı sonucuna ulaşılmaktadır. Sosyal medya kullanıcısı gençlerin kurumsal sosyal sorumluluk kampanyalarından haberdar olmaları ya da kampanyalara katılımları konusunda sosyal medya fenomenlerinin etkili işlevleri olabileceği ancak söz konusu etkinin fenomenin takipçi sayısının çok olması, ünlü olması ya da demografik özellikleri gibi değişkenlerden çok, sosyal medya fenomenine duyulan güven ile ilişkili olduğu görülmektedir. $\mathrm{Bu}$ bakış açısıyla birden çok nedenle gerçekleştirilen kurumsal sosyal sorumluluk kampanyalarının iletişiminde, sanal ortamların dijital paydaşları olarak takipçileri tarafından güven duyulan sosyal medya fenomenleri önemli rol üstlenebilir. 18-29 yaş aralığında sosyal medya kullanım oranının \%83 olduğu ülkemizde, kamuoyu önderi işleviyle kurumsal sosyal sorumluluk kampanyalarının iletişiminde desteği alınacak sosyal medya fenomenlerinin güven duyulan iletişim kaynağı olmasına ise özellikle dikkat edilmesi gerekmektedir. 


\section{Referanslar}

Bone, P.F. (1995). "Word of mouth effects on short-term and long-term product judgements", Journal of Business Research, Vol:32, No:3, 213-23.

Cho, Y., Hwang, J., \& Lee, D. (2012). Identification of effective opinion leaders in the diffusion of technological innovation: A social network approach. Technological Forecasting and Social Change, 79(1), 97-106.

East, R., Hammond, K., \& Wright, M. (2007). The relative incidence of positive and negative word of mouth: A multi-category study. International journal of research in marketing, 24(2), 175-184.

Peltekoğlu, F. B., \&Tozlu, E. (2017). Halkla İlişkiler ve Gönüllülük Ekseninde Türkiye'de Kurumsal Sosyal Sorumluluk Projeleri ve Bin Yıl Kalkınma Hedefleri. Danışma Kurulu, 5.

Peltekoğlu, F. B. (2016). Halkla ilişkiler nedir. Beta Basım Yayım Dağıtım., 223

Peltekoğlu, F. B. (2010). Kavram ve Kuramlarıyla Reklam. Beta Basım Yayım Dağıtım., 29

Rosen, E. (2000). The anatomy of Buzz: creating word-of-mouth marketing. HarperCollins., 42-44

Sheth, J. N., Gardner, D. M., \& Garrett, D. E. (1988). Marketing theory: evolution and evaluation (Vol. 12). John Wiley \& Sons Inc.

Silverman, G. (2006), Ağızdan ă̆ıza pazarlama, Mediacat Yayınları, Çeviren:Ender Orfanlı; İstanbul.,72

Stokes, D., \& Lomax, W. (2002). Taking control of word of mouth marketing: the case of an entrepreneurial hotelier. Journal of small business and enterprise development, 9(4), 349-357.

Kağıtçıbaşı, Ç. (1979). İnsan ve İnsanlar, 3. b. Cem Ofset AŞ.,169

http://www.dijitalajanslar.com/internet-ve-sosyal-medya-kullaniciistatistikleri-2017/ [Çevrim içi 04.03.2018]

http://sosyalmedyakulubu.com.tr/sosyalmedya/sosyal-medyayi-en-cok-kimlerkullaniyor-infografik.html [Çevrim içi 04.03.2018] 
